\title{
PERAN KELENJAR SEBASEA PADA ALOPESIA ANDROGENIK
}

\author{
Rahma M. Fahruddin \\ Sonny J. R. Kalangi \\ Taufiq F. Pasiak
}

\author{
Bagian Anatomi-Histologi Fakultas Kedokteran Universitas Sam Ratulangi Manado \\ Email: RahmaMegawatiFahruddin@ymail.com
}

\begin{abstract}
In the scalp there are about 100,000 hair shafts, made of dead keratinized tissues and hair follicles. Each hair follicle has a three-phase growth cycle: anagen, catagen, and telogen. Due to these, human hair grows discontinuously, with phases of growth followed by phases of rest, and does not fall simultanously, called mosaic growth pattern. Androgenic alopecia is the most common cause of hair loss and thinning in humans, which affects men and women. The sebaceous gland has an important role in the occurrence of androgenic alopecia. Recent advances in studies of hair growth show that selective and high safety drugs are needed in the management of androgenic alopecia. Substances that can be used are as follows: growth stimulators, DHT inhibitors, anti-inflammatory, anti-androgen, and super oxide dismuse substances.
\end{abstract}

Key words: hair, hair folicle, androgenic alopecia, sebacceous gland.

\begin{abstract}
Abstrak: Pada kulit kepala terdapat sekitar 100.000 batang rambut yang terbuat dari jaringan tanduk mati dan folikel tempat tumbuh rambut. Setiap folikel rambut memiliki tiga tahap periode pertumbuhan, yaitu anagen, katagen, dan telogen. Adanya ketiga tahap ini menyebabkan pertumbuhan rambut 'mozaik' dimana rambut tidak memanjang sekaligus dan rontok secara bersamaan. Alopesia androgenik merupakan penyebab paling umum kehilangan dan menipisnya rambut baik pada laki-laki maupun perempuan. Kelenjar sebasea berperan penting pada proses terjadinya alopesia androgenik. Dengan kemajuan terbaru dalam studi pertumbuhan rambut, pemilihan obat yang selektif dan aman menjadi pemecahan masalah utama bagi alopesia androgenik. Obat-obat yang dapat digunakan yaitu growth stimulator, DHT inhibitor, anti-inflamasi, anti-androgen, dan super oxide dismuse.
\end{abstract}

Kata kunci: rambut, folilkel rambut, alopesia androgenik, kelenjar sebasea.

Pada kulit kepala terdapat sekitar 100.000 helai rambut yang terdiri dari batang terbuat dari jaringan tanduk yang mati dan folikel tempat tumbuh rambut. ${ }^{1}$ Dalam siklus pertumbuhan rambut terdapat tiga fase dan terjadi pada masing-masing rambut pada waktu yang berbeda-beda. ${ }^{2}$ Pada awal masa dewasa, kehilangan $1 \%$ rambut di kepala masih normal. Bagi sebagian besar orang, kerontokan rambut yang serius tidak menjadi masalah sampai mencapai usia 50 tahun. ${ }^{3}$ Gambaran penipisan rambut atau terlihatnya tempat kebotakan terdapat di puncak kepala, di depan kepala, dan di tengah, tetapi pada umumnya yang paling jelas terlihat yaitu meningginya garis rambut (dahi semakin lebar). ${ }^{4}$ Rata-rata orang kehilangan 50 sampai 100 helai rambut setiap hari karena rontok, tetapi hampir semua tumbuh lagi digantikan dengan rambut baru. ${ }^{1}$

Kelenjar sebasea memiliki peran penting pada proses terjadinya alopesia androgenik. ${ }^{5}$ Sekitar 50 juta orang di Amerika mengalami kebotakan yang secara ilmiah dikenal sebagai alopesia androgenik (atau 
kebotakan biasa), tetapi bisa menjadi masalah yang sangat parah pada usia yang lebih muda. Laki-laki memiliki predisposisi genetik untuk keberadaan hormon androgen. ${ }^{3}$ Di Indonesia, sebagai salah satu negara terpolusi di dunia, sudah pasti terdapat banyak laki-laki dan perempuan yang mengalami masalah ini. Sebagian hanya mengalami penipisan, kebotakan pada kening, atau sampai botak total. Pada kebanyakan laki-laki di negara dunia ketiga seperti Indonesia, faktor kebotakan terjadi karena gabungan antara alopesia androgenik dan alopesia aerata. ${ }^{6}$

\section{SIKLUS RAMBUT NORMAL}

Pada awal kehidupan janin, kulit ditutupi oleh rambut lanugo. Generasi kedua dari rambut lanugo kemudian berkembang dan berlangsung sampai tiga atau empat bulan pertama kehidupan ekstra-uterin selesai. Setelah semua rambut lanugo menghilang, dua jenis rambut muncul, yaitu: vellus dan terminal. Vellus ialah rambut tipis dengan ukuran diameter $<0,1$ $\mathrm{mm}$, kadang-kadang berpigmen dan pendek (panjang $<2 \mathrm{~cm}$ ). Rambut terminal ialah rambut yang tebalnya sampai $0,6 \mathrm{~mm}$, panjang $>2 \mathrm{~cm}$, berpigmen, dan bermedula. $^{2}$ Folikel rambut memiliki kemampuan unik, yaitu beregenerasi sendiri sepanjang kehidupan organisme. ${ }^{7}$

\section{Anagen (pertumbuhan)}

Dalam kondisi normal, sekitar 90\% rambut tumbuh pada fase anagen atau masa awal pertumbuhan rambut, dengan siklus kehidupan yang bervariasi bagi setiap individu, yaitu antara tiga hingga lima tahun dengan rata-rata mengalami 20 kali regenerasi. Setiap bulan, rata-rata rambut tumbuh sepanjang $1-2,5 \mathrm{~cm}^{2}$

\section{Katagen (involusi / regresi)}

Usai fase anagen, rambut memasuki fase katagen atau masa istirahat selama dua sampai tiga minggu yaitu rambut sama sekali tidak tumbuh, sel-sel matriks secara bertahap berhenti membelah dan akhirnya keratinisasi. $^{2}$ Pada tahap ini, terdapat kematian sel yang terprogram secara alamiah (apoptosis) dari sel-sel folikel rambut, yaitu keratinosit dan melanosit folikel rambut. ${ }^{8}$ Ketika keratinisasi penuh tercapai, rambut memasuki fase telogen. ${ }^{2}$

\section{Telogen (istirahat)}

Pada tahap ini, mulai dibentuk batang rambut yang baru, dan segera masuk ke fase istirahat. Tahap telogen biasanya berlangsung selama tiga sampai empat bulan sebelum memasuki kembali fase anagen, dan selanjutnya siklus pertumbuhan rambut tersebut berulang-ulang. ${ }^{2}$ Folikel rambut kemudian memasuki masa eksogen (shedding/pelepasan), yaitu tahap ketika batang rambut yang lama mulai terlepas dari folikel rambut. ${ }^{8}$

\section{KELENJAR SEBASEA}

Kelenjar sebasea ialah kelenjar berkantong di dalam kulit. Bentuknya seperti botol dan bermuara di dalam folikel rambut. Kelenjar ini paling banyak terdapat di daerah kepala dan wajah, yaitu sekitar hidung, mulut dan telinga, tetapi sama sekali tak terdapat dalam kulit tapak tangan dan telapak kaki. Kelenjar dan salurannya dilapisi sel epitel. Perubahan di dalam sel ini menghasilkan sekresi berlemak yang disebut sebum. Kelenjar sebasea berada pada sudut antara folikel rambut dan otot pili erektor, sehingga kontraksi otot dapat mempengaruhi pengeluaran sebum dari kelenjar. $^{5}$ Kelenjar sebasea berfungsi mengontrol sekresi minyak ke dalam ruang antara folikel rambut dan batang rambut yang akan melumasi rambut sehingga menjadi halus, lentur, dan lunak, serta dapat mencegah kekeringan kulit dan rambut. ${ }^{9}$

Kelenjar sebasea merupakan bagian dari unit pilosebasea. Produksinya kaya akan lemak (sebum) dan mengalir melalui duktus masuk ke dalam folikel rambut. Kelenjar ini tergolong kelenjar holokrin dimana sebum cenderung terbentuk karena hancurnya sel-sel kelenjar dan bukan kare- 
na proses sekresi yang aktif. ${ }^{10}$ Kelenjar sebasea terdapat dalam jumlah banyak sewaktu bayi lahir, karena pengaruh hormon ibunya, tetapi kemudian mengalami atrofi, dan tidak membesar lagi sampai pubertas. ${ }^{11}$

\section{ALOPESIA ANDROGENIK}

Alopesia androgenik (juga dikenal sebagai androgenetic alopecia atau alopecia androgenetica) merupakan penyebab paling umum kehilangan dan menipisnya rambut pada manusia, ${ }^{12,13}$ yang ditandai dengan penurunan tajam dalam ukuran folikel rambut, yang dapat dikaitkan dengan hilangnya batang rambut folikel atau sel progenitor. ${ }^{14}$ Pada laki-laki, kondisi ini juga dikenal sebagai pola kebotakan laki-laki. Rambut hilang dalam pola yang jelas, mulai di atas kedua candi, dan membentuk karakteristik bentuk rambut "M". Rambut juga menipis di puncak (dekat bagian atas kepala), sering berkembang menjadi kebotakan parsial atau lengkap. Pada perempuan, rambut menjadi lebih tipis di seluruh kepala, dan rambut tidak surut. Alopesia androgenik pada perempuan jarang menyebabkan kebotakan total. Batas rambut depan biasanya dipertahankan, bagian atas verteks melebar jika dibandingkan dengan bagian belakang kepala, dan perempuan yang terkena tidak virilisasi. ${ }^{15}$ Skala Norwood (Norwood Scale) memperlihatkan perubahan distribusi rambut yang terjadi pada proses pembotakan secara umum (Gambar 1). ${ }^{16}$

Para peneliti telah menentukan bahwa bentuk kerontokan rambut terkait dengan hormon androgen, terutama golongan dihidrotestosteron yang disebut androgen. Peningkatan kadar androgen dalam folikel rambut dapat menyebabkan siklus pertumbuhan rambut menjadi pendek dan tipis pada helai rambut. ${ }^{15}$ Alopesia androgenik dapat dipantau dengan alat dermoscopy computer, yaitu suatu alat yang dapat mendeteksi diameter rambut. ${ }^{17}$ Meskipun alopesia androgenik bukan penyakit sistemik, sebagian penderita mengalami kecemasan tentang perkembangan kondisi mereka. ${ }^{18}$ Alopesia androgenik yang parah dapat memberikan tekanan psikologi yang cukup tinggi bagi penderita, ${ }^{19}$ berupa gangguan kecemasan sosial, yang ditandai dengan ketakutan, penghinaan, atau sedang dinilai negatif dalam situasi sosial. ${ }^{20}$
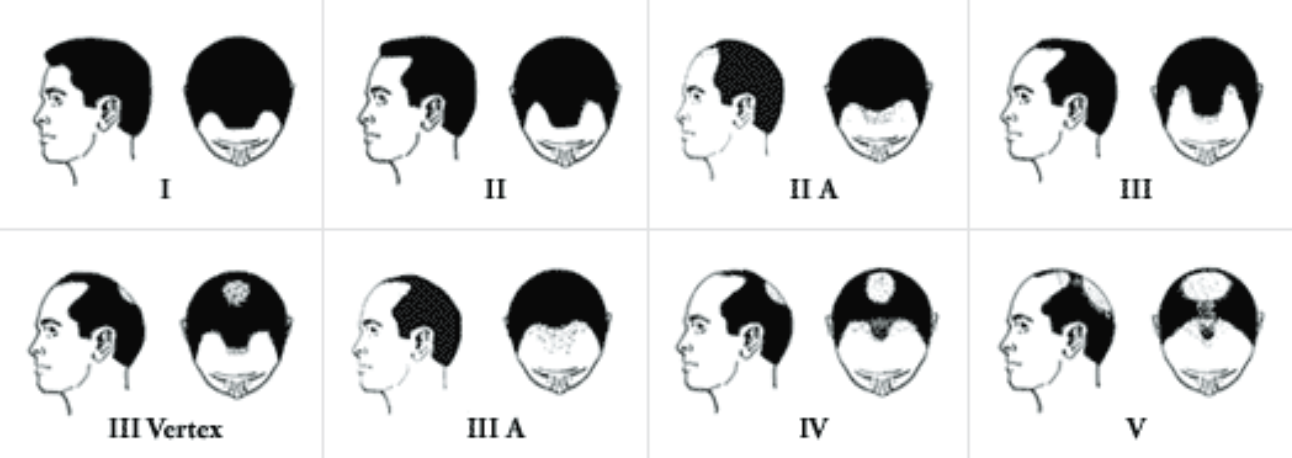

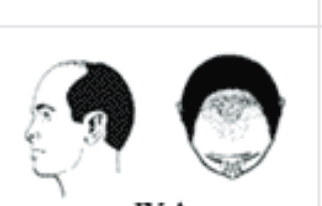

IV A
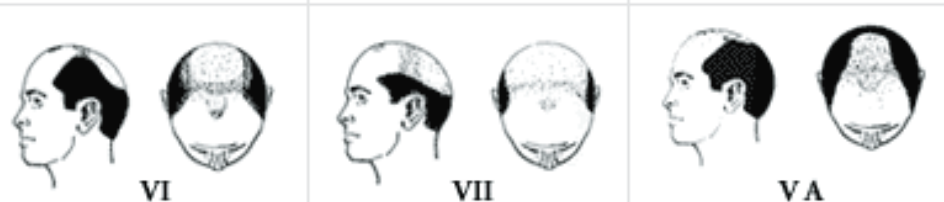

Gambar 1. Proses pembotakan menurut Skala Norwood Hamilton. Norwood I: Gambaran rambut normal. Norwood II-III: stadium awal kebotakan, ditandai dengan siklus pertumbuhan rambut yang mulai kacau (rambut hilang mulai dari kedua candi). Norwood III: garis rambut surut untuk membentuk karakteristik huruf "M". Norwood IIIA: dahi bertambah lapang. Norwood IV-IVA: stadium menengah, perubahan yang terjadi bersifat cepat. Norwood V-VA: dahi bertambah lapang dan meluas kebelakang. Norwood V-VII: stadium tingkat lanjut dimana telah terjadi kerusakan akut pada folikel dan reseptor papila. ${ }^{16}$ 


\section{PERAN KELENJAR SEBASEA PADA ALOPESIA ANDROGENIK}

Setiap folikel rambut memiliki siklus aktivitas tersendiri yang berbeda dengan siklus aktivitas folikel rambut lainnya. Oleh karena itu, pertumbuhan rambut manusia memiliki pola perumbuhan 'mozaik', yaitu seperti ubin mozaik dimana dalam satu ubin terdapat aneka corak dan warna. Bila seuntai rambut dipangkas rata, dalam pertumbuhannya nanti akan menjadi tidak rata lagi karena pada masing-masing rambut yang terpangkas, ada yang sedang dalam masa anagen, masa katagen, maupun masa telogen. Hal ini menyebabkan rambut tidak semuanya memanjang sekaligus, lalu rontok sekaligus semuanya. ${ }^{20}$

Kelenjar sebasea memiliki peran penting pada proses terjadinya alopesia androgenik. ${ }^{5}$ Rangsangan dari hormon androgen menyebabkan pembesaran kelenjar sebasea, dan memroduksi sebum yang kaya akan sekret berminyak. ${ }^{10,21}$ Oleh karena kelenjar sebasea berada pada sudut antara folikel rambut dan otot pili erektor, maka kontraksi otot tersebut dapat memengaruhi pengeluaran sebum dari kelenjar sebasea. ${ }^{5}$ Kontraksi muskuli arektor pili memaksa sebum keluar dari kelenjar sebasea lalu masuk ke dalam folikel rambut dan kulit. ${ }^{21}$ Di dalam folikel rambut terjadi akumulasi sebum. Produksi kadar sebum yang berlebihan dapat meningkatkan enzim 5alpha reduktase. Dalam folikel terdapat kandungan enzim 5-alpha reduktase, yang bertanggung jawab untuk mengonversi testosteron bebas menjadi dihidrotestoteron (DHT). DHT akan menempelkan dirinya ke folikel rambut, sehingga menyumbat poripori disitu yang akan menyebabkan keadaan kekurangan gizi dari akar sampai rambut sehingga folikel rambut menyusut (miniaturisasi) dan berhenti memroduksi rambut. $^{2}$

\section{PENATALAKSANAAN KERONTOKAN}

Bila keadaan yang terjadi masih berupa penipisan rambut, dapat disarankan untuk terlebih dahulu menggunakan obatobat yang membantu mempercepat pertumbuhan atau mengembalikan rambut yang hilang di kepala. Banyak kasus alopesia yang sembuh sendiri dengan berjalannya waktu tanpa perlu diobati. Pada umumnya, keberhasilan pengobatan tergantung dari penyebab kerontokan rambut itu sendiri. Untuk penatalaksanaan rambut rontok atau kebotakan dapat diberikan penyubur rambut, penghambat DHT, antiinflamasi, anti-androgen, dan super oksida dismutase. ${ }^{1,17,22}$

\section{Penyubur rambut}

Golongan obat ini bekerja secara simtomatis dengan merangsang partumbuhan rambut tanpa berhubungan langsung dengan penyebab kerontokan. Dari golongan ini, yang sering digunakan ialah minoksidil. ${ }^{1}$

\section{Penghambat DHT}

Golongan obat ini bekerja mencegah terkaitnya testos-teron dengan enzim 5-alfa reduktase membentuk DHT. Cara kerja kelompok obat ini pada 'akar' masalah penyebab kerontokan rambut tersebut, untuk mengembalikan kesehatan rambut. Dari golongan ini, obat yang sering digunakan ialah finasterid (Proscar $\left.{ }^{\circledR}\right){ }^{1}$ Tahun pertama pemakaian telah dapat membantu memprediksi efektifitas pengobatan. Pada $21 \%$ kasus, pengobatan berlanjut melampaui lima tahun memberikan hasil yang lebih baik. ${ }^{17}$

\section{Anti-inflamasi}

Golongan obat ini bekerja menghentikan radang yang terjadi akibat gangguan sistem imun sehingga dapat memulihkan kesehatan rambut. Dari golongan ini, yang sering digunakan ialah kortikosteroid dan antralin. ${ }^{1}$

\section{Anti-androgen}

Golongan obat ini bekerja mencegah DHT terikat pada reseptor androgen, 
sehingga dapat berfungsi sebagai inhibitor DHT. $^{22}$

\section{Super oksida dismutase (SOD)}

Golongan obat ini bekerja memperbaiki sistem imun, sehingga dapat berfungsi sebagai anti-inflamasi dan sekaligus growth stimulator. ${ }^{1}$

\section{SIMPULAN}

Kelenjar sebasea merupakan bagian dari unit pilosebasea yang memroduksi sebum. Umumnya rangsangan hormon androgen pada kelenjar sebasea merupakan penyebab alopesia androgenik, yang mengakibatkan miniaturisasi folikel rambut, kerontokan, dan terhentinya pembentukan rambut. Pemilihan obat yang baik, selektif, serta aman menjadi pemecahan masalah utama bagi alopesia androgenik.

\section{DAFTAR PUSTAKA}

1. Elex Media Komputindo. Mencegah kebotakan dini. Jakarta: Gramedia, 2011; p.x-6.

2. Slobodan MJ, Snezana VJ. The Control of hair growth. Dermatol J. 2006:4(1):2.

3. David R. Look Ten Years Younger, Live Ten Years Longer, A Man's Guide. Batam: Interaksara, 1998; p.309-310.

4. Gordon KA, Tosti A. Alopecia: evaluation and treatment. Clin Cosm Invest Dermatol. 2011;4:101-6.

5. Sloane E. Anatomi dan Fisiologi Untuk Pemula. Jakarta: EGC. 2004; p.293, 403.

6. Hoery AS. Medical and beauty [homepage on the Internet]. c2010 [update 2010 Oct 30; cited 2011 May 30]. Available from: http://www. Medicoensudomicilio.com/paginas/english/medicaladvice-to-treat-and-prevent -hair-lossbaldness-or-alopecia.html.

7. Novak MA, Meyer JS. Alopecia: possible causes and treatments, particularly in captive nonhuman primates. Compar Med. 2009; 59(1):18-26.

8. Prajitno S, Djuari L. Alopecia. [homepage on the Internet]. c2010 [update 2010 Oct 30; cited 2011 May 30]. Available from:.www.klinikdrsuburprajitno.com

9. Willms JL, Schneiderman H, Algranati PS. In: Widjaja AC, Sadikin V, Setio M, editors. Diagnosis Fisik: Evaluasi Diagnosis \& Fungsi di Bangsal. Jakarta: ECG, 2005; p.71.

10. Corwin EJ. Buku Saku Patofisiologi Corwin. Jakarta: EGC, 2009; p.102.

11. Brown RG, Burns T. Lecture Notes on Dermatology (Eight Edition). Jakarta: Erlangga, 2005; p.6, 135.

12. Soni VK. Ensiklopedia Androgenic Alopesia [homepage on the Internet]. c2010 [update 2010 Nov 12; cited 2009]. Available from: http://en.wikipedia.org/wiki/Androgeni c_alopecia.

13. Nardi AE. Psychological impact of alopecia, Alopecia may lead to social anxiety. Br Med J. 2005;331(7524): 1084.

14. Garza LA, Chao CY Bald scalp in men with androgenetic alopecia retains hair follicle stem cells but lacks CD200-rich and CD34-positive hair follicle progenitor cells. J Clin Invest. 2011;121(2):613-22.

15. Genetic home reference. US National Library of Medicine. Alopesia Androgenik [homepage on the Internet]. c2011 [update 2011 Jan 5; Cited 2011]. Available from: http://ghr.nlm.nih.gov/condition/androg enetic-alopecia.

16. Difference between androgenic alopecia and female baldness [homepage on the Internet]. c2010 [update 2010 Des 15; cited 2008]. Available from: http://www.baldingblog.com/2008/09/0 2/difference-between-androgeneticalopecia-and-female-baldness/.

17. Malgorzata $O$, Lidia R. Effective treatment of female androgenic alopecia with dutasteride. J Drugs in Dermatol. 2005;19(7):756-766.

18. Yamazaki M, Miyakura T. Oral finasteride improved the quality of life of androgenetic alopecia patients. Dermatol J. 2011;38(8):773-7.

19. Hunt N, McHale S. The psychological impact of alopecia. BMJ. 2005; 331:951-3.

20. Kusumadewi. Rambut anda: masalah, perawatan, dan penataannya. Jakarta: Gramedia, 2003; p.34-35. 
21. Victor PE. Atlas Histologi de Fiore dengan kolerasi fungsional (Edisi Kesembilan). Jakarta: EGC, 2003; p.138.
22. Scheinfeld N. A Review of hormonal therapy for female pattern androgenik alopecia. Dermatol Med J. 2011;14 (3):1. 